\title{
Selected Reference Books of 1982-83
}

\section{Eugene P. Sheehy}

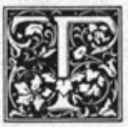

his article continues the semiannual series originally edited by the late Constance M. Winchell. Although it appears under a byline, the list is a project of the reference departments of Columbia University's Butler and Lehman libraries, and notes are signed with the initials of the individual staff members. ${ }^{1}$

Since the purpose of the list is to present a selection of recent scholarly and general works of interest to reference workers in university libraries, it does not pretend to be either well balanced or comprehensive. A brief roundup of new editions of standard works, continuations, and supplements is presented at the end of the article. Code numbers (such as AE213, CJ34) have been used to refer to titles in the Guide to Reference Books and its supplements. $^{2}$

\section{BIBLIOGRAPHY}

Internationale Jahresbibliographie der Festschriften ... mit Verzeichnis aller Beiträge, einem Autorenregister und einem Sachregister zu den Festschriften. Jahrg. 1- , 1980- . Osnabrück, Biblio Verlag, 1982- . Annual. ISBN 3-7648-1276-1.

At head of title: IJBF.

Intended as a continuation of the forthcoming second edition of Otto Leistner's Internationale Bibliographie der Festschriften (1st ed. 1976; Suppl. AA27), which is to cover through 1979, this series will pro- vide annual listings of new homage volumes published throughout the world. In the first section, Festscrhiften are listed alphabetically by name of the person or institution honored; full bibliographical information is given, together with a list of the contents. (A number of works are listed without contents notes; these are to be analyzed in future issues of the IJBF.) An "author index of the contributions" gives the author and title of each contribution, with reference to the name of the honoree. Subject indexing is to the overall content of the homage volume not to the individual contributions; a subject index using English terms gives reference to the corresponding German headings. It seems unfortunate that so large a portion of the volume is devoted to repetition of the titles of the contributions when a simple author index would have sufficed. Would that the space and effort expended there had been directed toward detailed subject indexing of specific contributions! $-E$.S.

Kenya National Bibliography, 1980Nairobi, Kenya National Library Service, National Reference \& Bibliographic Dept., [1983]- . Annual. KSh 95.00 in Kenya (\$15.50 in U.S.A.).

The subtitle of this new annual virtually says it all: "A classified subject bibliography of current publications produced in Kenya \& foreign materials of interest to Kenya and/or written by Kenyans, arranged according to the Dewey Decimal

1. Anita Lowry, Eileen Mcllvaine, Louise Sherby, Junko Stuveras; Lehman Library: Laura Binkowski, Diane Goon.

2. Eugene P. Sheehy, Guide to Reference Books (9th ed.; Chicago: American Library Assn., 1976); Supplement (Chicago: American Library Assn., 1980); Second Supplement (Chicago: American Library Assn., 1982). 
Classification and catalogued according to the Anglo-American Cataloguing Rules, with a full author \& title index." The bibliography is based on publications received at the National Library under the legal deposit act of 1962, supplemented by materials acquired by the library through purchase, gift, and exchange. Books, research reports, conference proceedings, pamphlets, maps, first issues of new serials (and subsequent title changes) are included, together with selected audiovisual and nonprint materials. Foreign publications of interest to Kenya and works by Kenyans published abroad are marked with an asterisk. The preface alludes to a proposed retrospective bibliography for pre-1980 imprints and to a possible cumulation of the annuals. $-E$.S.

\section{ARCHIVES}

Foster, Janet and Sheppard, Julia. British Archives; A Guide to Archive Resources in the United Kingdom. London, Macmillan; Detroit, Gale, 1982. 533p. \$65. LC 82-18373. ISBN 0-8103-1126-7.

Having first planned to cover nineteenth- and twentieth-century archival materials in specialist repositories, the editors soon noted the lack of an adequate subject index to other types of repositories and expanded their project to include all types of archives. The primary object of the resulting guide is to give a subject approach to archival resources as "a starting point for the first-time user of archives." - Introd. It includes archives "in the widest sense of the word" which are made "relatively accessible" to any interested party.

The 708 entries are essentially based on the replies to questionnaires sent to approximately 750 libraries, with the amount of detail depending on the reply received. On-site investigation was not conducted. Besides the practical information such as address, telephone, opening hours, and the name or title of the person to whom an inquiry should be addressed, a typical entry includes a note on the history of the institution, collection policy, major collections, nonmanuscript materials (photographs, drawings, etc.), finding aids (in- ventories, catalogs, indexes), facilities (reading room, photocopier, microfilm reader, etc.), and publications describing the holdings. Entries are arranged alphabetically by name of city or town. There is a list of the archives by county, then by name of repository. The general index to collections is mainly an index by personal name; the "key subject word list" indexes the entries by very broad subject fields such as biochemistry, animals, classical studies, drama, Jesuits, ships, and shipbuilding. The guide also provides a select bibliography (p.521-22) and offers practical advice to beginning researchers.-J.S.

\section{Women Religious History Sources: A Guide to} Repositories in the United States. Ed. by Evangeline Thomas. N.Y., Bowker, 1983. 329p. \$65. LC 82-22648. ISBN 0835-21681-0.

Building on the results of workshops and a survey sponsored by the Leadership Conference of Women Religious, archivists have compiled a description of the document repositories of 569 orders of sisters, nuns, and deaconesses of the Catholic, Orthodox, Episcopal, Lutheran, Methodist, and Mennonite churches. The definition of an order suitable for inclusion was broad enough to cover active as well as contemplative orders: "any congregation/community of vowed women religious who had maintained a continuity over many years in the manuscript and archival collections that document their corporate and individual contributions to Church and American society." -Pref. Most of the information was obtained through questionnaires, with a cross section of some forty repositories chosen for visits by the compilers.

For each site a brief history is given, together with address and membership (total and present), followed by a description of the archival holdings and indication of any finding aids and whether photocopying is allowed. There is a list of reference numbers at the end of each entry leading the user to an alphabetical list of foundresses and major superiors, with dates. Besides this biographical register, two other appendixes are included: a bibliography of biographies and histories- 
published, privately printed, or mimeographed-arranged alphabetically by keyword (e.g., Adorers, Benedictines); and a table of United States founding dates of orders, 1727-1977, with date, country of origin, first American location, and present location.

There is a very useful index with topical, order name, and personal name entries; here one can find reference to all the entries for Elizabeth Seton or to those orders involved in social services or in nursing care during a particular war. The specialized nature of the material-and the price-may make this excellent guide of interest only to research libraries and, of course, to similar archives.-E.M.

\section{DICTIONARIES}

Neaman, Judith S. and Silver, Carole G. Kind Words: A Thesaurus of Euphemisms. N.Y., Facts On File, [1983]. 320p. \$16.95. LC 82-7391. ISBN 0-87196-426-0. According to the authors of this book, a euphemism is pretty much in the eye (or ear) of the beholder-a policy that enables them to collect all manner of slang, vulgarisms, jargon, acronyms, etc., into the category of words that at least some people would rather use than the real name for something. This thesaurus is selective, concentrating primarily on euphemisms relating to the "subjects we consider most basic to human thought and languagelove, death, the human body. In selecting specific entries, we have considered such factors as: frequency of usage, historical interest, richness of linguistic association, unusual color or flavor and social implications." - p.vii. The definitions are highly readable and are sensitive to nuances of usage and meaning and to relations among euphemisms; the historical background, etymologies, and quotations are interesting and informative.-A.L.

\section{GOVERNMENT PUBLICATIONS}

Official Publications of the Soviet Union and Eastern Europe, 1945-1980: A Select Annotated Bibliography. Ed. by Gregory Walker. London, Mansell (dist. in U.S. by H. W. Wilson), 1982. 620p. \$64. LC 82-200730. ISBN 0-7201-1641-4.
In states where political, economic, and social activities are subject to strong centralized control and single-party leadership, "official publications" are all the more significant to researchers because publications that compete with or critique the official line are virtually nonexistent. Walker and his colleagues have produced an indispensable guide to this literature. For purposes of this volume, the definition of "official publications" has been interpreted very broadly to include those publications " issued by or on the order of the established government or party authorities which intend to direct and regulate the life of the country, which supply information believed to be necessary for its proper functioning, or which publicize and justify the policies of its rulers." Pref. Categories include constitutions, treaties, legislation, statistical sources, party documents, official statements, and speeches. The compilation is not exhaustive; only the most important materials published between 1945 and 1980 are included.

There is a chapter for each country and one devoted to international and multinational official publications. Each chapter, compiled by a specialist, begins with a brief outline of the major political and administrative developments of the postwar period. The citations are grouped under topical headings such as law codes, party documents, international relations, political, military, economic, social and cultural affairs, and leaders' works. Complete bibliographic information is given, including an English translation of the title, and the annotations are brief but informative. English, French, or German translations are noted when available. An author, editor, compiler, and title index concludes the work.-L.B.

\section{DISSERTATIONS}

Sluglett, Peter. Theses on Islam, the Middle East and North-West Africa, 1880-1978, Accepted by Universities in the United Kingdom and Ireland. [London], Mansell, [1983]. 147p. \$28. LC 83-204503. ISBN 07201-1651-1.

More than three thousand British and 
Irish theses at both the master's and doctoral level are listed in this bibliography. Sections for "Islamic Studies," "Islam Outside the Middle East and North-West Africa," "Arabic Studies," and "Christianity in the Middle East and North Africa since the 7th Century" precede the geographical sections with their topical subdivisions. The introduction notes that "while the countries of the Middle East and North-West Africa, and the Mediterranean islands of Cyprus and Malta are covered as fully as possible, the rest of the Islamic world is only covered in so far as Islam and Muslims are concerned." There are author and subject indexes, but many of the entries in the latter are too broad to be really useful. Indication that a given item has been microfilmed for the Lending Division of the British Library (and thereby available for loan or further reproduction) is a helpful feature.-E.S.

\section{BIOGRAPHY}

Logan, Rayford W. and Winston, Michael R., eds. Dictionary of American Negro Biography. N.Y., Norton, 1982. 680p. \$49.50. LC 81-9629. ISBN 0-393-01513-0.

This welcome volume fills a gap in the subject of Negro biography. Inasmuch as the work is intended as a scholarly resource, the emphasis for inclusion was historical significance of the biographee, not "fame." The editors recognized that this significance could mean different things at different times, just as great achievements in the seventeenth century might be judged differently in the nineteenth. Many of the biographees were not "national" figures, but rather achieved recognition on a local or regional basis. Only figures who died prior to 1970 are included. Article length is not necessarily indicative of importance but, rather, may reflect the dearth of information available. Each entry includes a bibliography and is signed by the contributor. - L.S.

\section{LINGUISTICS}

Greimas, Algirdas Julien and Courtés, Joseph. Semiotics and Language: An Analytical Dictionary. Tr. from the French by
Larry Crist [and others]. Bloomington, Indiana Univ. Pr., [1982]. 409p. \$35. LC 81-47828. ISBN 0-253-35169-3.

The authors propose this rather ambitious work (original title: Sémiotique) as a "' dictionnaire raisonné', that is, a systematic presentation, in the form of concise and up-to-date reflections, of all system(s) and/or process(es)."'-Pref. By defining the terms and concepts of contemporary semiotic/linguistic theory and by indicating the relationships among them, the authors seek to contribute to the "elaboration of a rigorous conceptual metalanguage which is a necessary preliminary toward the establishment of any language theory as formal language." This is not a dictionary for the uninitiated, but one for scholars and advanced students of semiotic theories in linguistics, literature, and other fields. In it they will find detailed (and extremely dense) analytical definitions, ranging in length from a paragraph to several pages, for the essential terminology of semiotics. The terms (referred to as "Head Words") are arranged alphabetically and are followed by the original French terms in parentheses. A three-tiered system of crossreferences within the body and at the end of each definition enables (indeed, requires) the reader to understand and interpret the terms in relation to one another within the broader theoretical framework proposed by the authors. An appendix of "French Head Words with English Equivalents" enables readers to find French terms in the dictionary under their English translations. A substantial selected bibliography completes the volume, which is both sturdy and handsome.-A.L.

\section{LITERATURE}

Thompson, George. Key Sources in Comparative and World Literature: An Annotated Guide to Reference Materials. N.Y., Ungar, [1982]. 383p. \$40. LC 82-40253. ISBN 0-8044-3281-3.

Over the years, students of comparative literature have not been well provided with bibliographic guides. Intended for the graduate student, this work goes some way toward filling the gap, but emphasis 


\section{YOU AND YOUR STAFF now can stay continuously in touch with current Federal technical information through Government Reports Announcements and Index (GRA\&I).}

Each journal contains about 2,500 bibliographic citations, biweekly, of recently completed research compiled and published by the National Technical Information Service (NTIS). A subscription to GRA\&/ means an automatic technological update every two weeks.

And every GRA\&l journal includes these five indexes to provide easy access to and selection of just the reports you need:

- Keyword

- Personal Author

- Corporate Author

- Contract/Grant Numbers

- Accession/Report Numbers

In the course of a year's subscription you can turn to some 70,000 technical reports of research carried on in the labs of Federal agencies, universities, and industry. And GRA\&I can be a helpful guide to the NTIS Bibliographic Data Base online.

Discover the single-source guide to a wealth of new technology including:

Aeronautics - Agriculture - Astronomy \& Astrophysics - Atmospheric Sciences Behavioral \& Social Sciences • Biological \& Medical Sciences $•$ Chemistry • Earth Sciences \& Oceanography • Electronics \& Electrical Engineering - Energy Conversion - Non-Propulsive - Materials - Mathematical Sciences - Mechanical, Industrial, Civil \& Marine Engineering $\cdot$ Methods \& Equipment - Military Sciences - Missile Technology $\bullet$ Navigation, Communications, Detection \& Countermeasures $\cdot$ Ordnance - Physics • Propulsion \& Fuels • Space Technology.

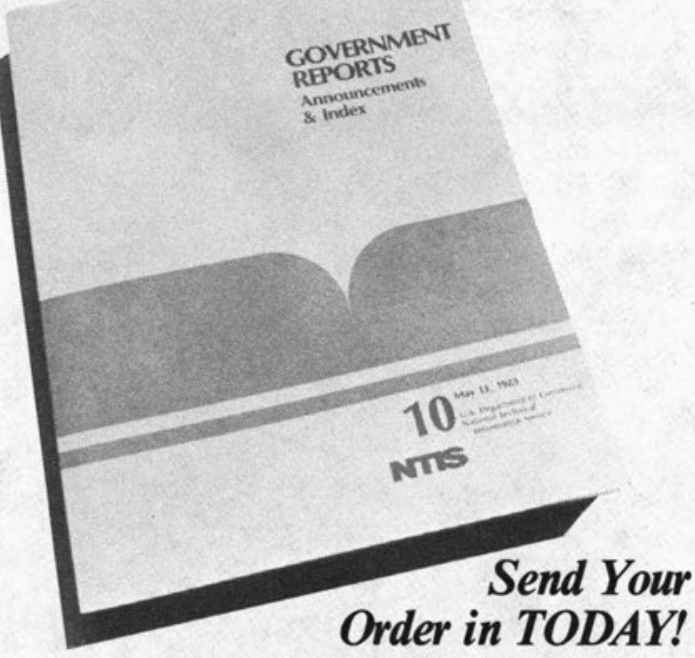

ORDER CARD

$\square$ YES! I want to receive Government Reports Announcements and Index. Please start my subscription immediately. I understand the subscription rate to be $\$ 325$ annually. DB-83-900100 AAS

$\square$ Here is my check for $\$$

$\square$ Charge to my NTIS Deposit Account No. Charge to:

$\square$ American Express $\square$ VISA $\square$ MasterCard Account No. Exp. Date

Signature (Required to validate order)

Name

Occupation

Organization

Address

City, State, ZIP

U.S. DEPARTMENT OF COMMERCE National Technical Information Service 5285 Port Royal Road

Springfield, VA. 22161 
Now UMI puts articles from 7,500 publishers at your fingertips.

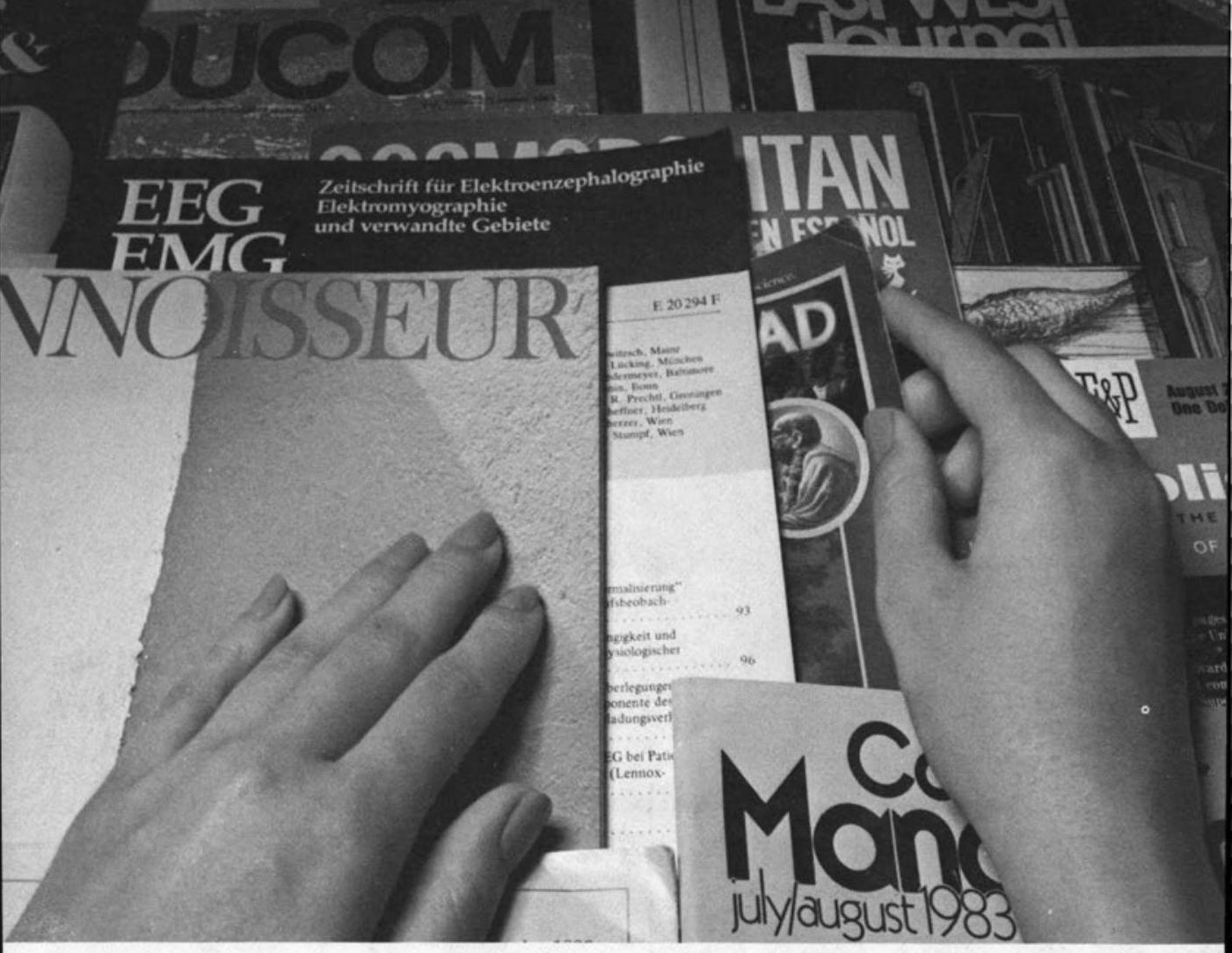


On Microfilm...from Research Publications

\section{Free 1983 backfile with your 1984}

newspaper subscription.

Research Publications brings the world's news to you as reported in 27 international newspapers including the following newspapers with their 1984 subscription prices:

The Washington Post $\$ 740.00$

The Times

640.00 Neue Zurcher Zeitung 540.00

The Sunday Times 285.00 Le Monde 400.00

Der Spiegel $\quad 140.00$ Financial Times $\quad 550.00$

Far Eastern Economic Review 105.00

Free Backfile Offer. Order your 1984 newspaper

subscription before March 31, 1984 and we will include the entire 1983 backfile for that newspaper at no extra charge. This offer is limited to customers who have not been subscribers for the last two years to the particular newspaper ordered. Shipping and handling charges will be

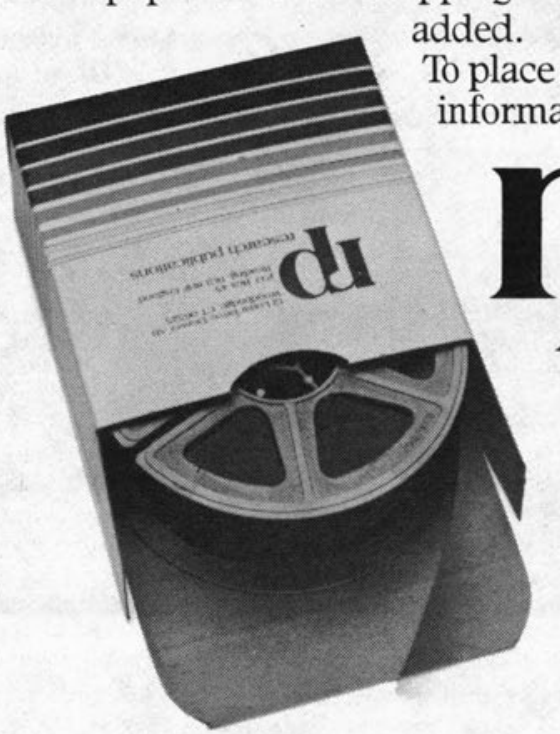

research publications

Research Publications 12 Lunar Drive/Drawer AB Woodbridge, CT 06525 (203) 397-2600 TWX: 710-465-6345 FAX: 203-397-3893 
here is on specific world literatures rather than on comparative literature as such. Moreover, "the topic of international relations and influences is touched on only in reference to the influence of the classical literatures on later literatures" (Introd.), and we are thrown back on works such as Baldensperger's bibliography (Guide BD1) for that type of search.

A section on comparative, general, and international literature is followed by chapters for classical, Romance, French, Italian, Hispanic, and German literatures, literature in English (the most extensive section of the book), other European literatures, Oriental literatures, and related fields. Methods of literary study and theories of literary criticism are not covered. Among the types of reference sources cited are bibliographies and surveys of research (including many serial bibliographies), handbooks, dictionaries of critical terms, literary encyclopedias, biographical dictionaries, and literary histories. For some 160 individual writers, concordances and special indexes are cited. Annotations frequently compare the sources with similar publications, and reviews are cited selectively. There is an index of bibliographers, editors, compilers, etc., a selective index of titles and institutions, and an index of subjects.-E.S.

\section{FILM STUDIES}

\section{Magill's Cinema Annual, 1982- . Engle- wood Cliffs, N.J., Salem Pr., [1982]-} Annual. \$33.25. ISSN 0-89356-400-1. The 1982 volume of this new series covers selected films released in 1981 and earlier and serves as a supplement to Magill's Survey of World Cinema (1981, 6v.), conforming to its format and style. As a yearby-year record of films released in the United States, Magill's Cinema Annual is much less comprehensive than the longrunning Screen World (Guide BG134), which lists more complete credits and attempts to include all feature-length films released here; Magill's is quite selective and is particularly weak on foreign films (of which only nineteen are included for 1981). However, Magill's includes lengthy plot summary and commentary for each of the films selected, plus a list of reviews in newspapers and popular periodicals. $\mathrm{Ma}$ gill's indexes (not as complete as Screen World's) are by title, director, screenwriter, cinematographer, editor, art director, music, and performer. In addition, Magill's has a subject index which is a unique and useful feature. The "Obituaries'" section provides a considerable amount of information about film people who died during the year. The volume also includes lists and essays on various film topics; the award lists would be more useful if they were complete, and the essays are aimed at a very general and unsophisticated audience. $-A . L$.

\section{PHOTOGRAPHY}

Contemporary Photographers. Ed. by George Walsh [and others]. N.Y., St. Martin's Pr., [1982]. 837p. il. \$70. LC 823337. ISBN 0-312-16791-1.

The 650 photographers from around the world who are included in this hefty volume were chosen "to reflect the best and most prominent of contemporary photographers (those who are living and those who have died in the recent past); photographers from earlier generations whose reputations are essentially contemporary; and photographers from the inter-war years and after who continue to be important influences." - p.vii. These are the photographers, both familiar and lesser known, whose work illustrates and defines the expressive potential of the photographic medium.

Drawing on an extensive network of expert advisers and contributors as well as on library and museum resources and on the photographers themselves, the editors have produced a scholarly reference source that combines biobibliographical information with critical assessment for each photographer. Each entry consists of a short biography, a list of individual exhibitions (including two- and three-person shows), a selected list of group shows, a selected list of public galleries and museums having the photographer's work in their collections, a bibliography of books and articles by and about the photographer, a signed critical essay, a reproduc- 
tion of a representative photograph, and a personal statement (from those living biographees who chose to contribute one). In addition, the "Notes on Advisers and Contributors" at the end of the volume provides brief biographical information on approximately 155 critics and historians of photography. Future editions are projected at intervals of five years. $-A . L$.

\section{FOLKLORE}

Handbook of American Folklore. Ed. by Richard M. Dorson. Bloomington, Indiana Univ. Pr., 1983. 584p. \$35. LC 82-47574. ISBN 0-253-32706-7.

This is not an encyclopedia or dictionary for ready-reference use. The late R. M. Dorson has assembled an impressive array of sixty-eight essays by sixty contributors from all over America, providing "an introduction to American folklore as it has been studied in America" (Introd.) in a work more suitable to be read from cover to cover than to be consulted for quick reference.

The outcome of a project conducted from 1976 to 1982 with the support of a grant from the Research Materials Program of the National Endowment for the Humanities, the volume offers a comprehensive survey of folklore studies. The essays are presented in four groups: topics of research, interpretation of research, methods of research, and presentation of research. Each essay averages ten pages in length, covers one aspect of folklore studies (ranging from a particular type of folklore to a discussion of teaching graduatelevel courses on folklore), and is generally well documented by bibliographic notes. There is a substantial bibliography (p.541-63) which covers the literature of the field up to about 1980 and is arranged under seven headings: American folklore bibliographies, American experiences, American settings, American forms and performers, interpretations, methods, and presentation. The book is fully indexed. This is a useful professional tool for the scholar and a good source for anyone wishing to inform himself of the state of the art in folklore studies.-J.S.

\section{SOCIOLOGY}

The Encyclopedia of Alcoholism. Ed. by Robert O'Brien and Morris Chafetz. N.Y., Facts On File, 1982. 378p. il. \$40. LC 8112562. ISBN 0-87196-623-9.

All aspects of alcoholism, including the substance alcohol itself, the social institutions created to help treat alcoholism, and the physical and psychological symptoms of alcoholism are touched on in this concise volume. Articles vary in length from a single sentence (e.g., "substance abuse") to several pages (e.g., "Alcoholics Anonymous"); many include a short bibliography. References to articles dealing with terms used in the text and see also references are indicated by use of capital letters; cross-references from variant forms to the terms actually used are also included (e.g., "National Prohibition Act see Volstead Act"). Charts and tables are used sparingly in the body of the work, but Appendix 1 comprises a major section of tables and figures on such topics as alcohol education, blood alcohol content, and the numbers of arrests for drunken driving. Appendix 2 contains a list of major information sources on alcoholism in the United States and Canada as well as in some foreign countries. Following the appendixes is a substantial bibliography of monographs on alcoholism, and there is a subject index. A very useful volume, appropriate for both the professional and the layperson.-L.S.

Shearer, Barbara Smith and Shearer, Benjamin, F. Periodical Literature on United States Cities; A Bibliography and Subject Guide. Westport, Conn., Greenwood Pr., 1983. 574p. \$49.95. LC 82-24211. ISBN 0-313-23511-2.

The compilers have brought together a most useful selection of citations to " 4,919 periodical articles on the 170 United States cities having a population of 100,000 or more." -Pref. From Akron, Ohio, to Youngstown, Ohio, cities are listed alphabetically in the main body of the work. The bibliography includes articles published from 1970 to 1981 , selected on the basis of the value of the information and its proba- 
ble availability nationwide. Therefore, articles published only locally and those of limited value are excluded. Articles are grouped in eight categories (general, architecture and the arts, education and the media, environment, government and politics, housing and urban development, social and economic conditions, and transportation), but not all categories appear for each city. Categories listed for a given city are merely indicative of what was published on those topics during the period covered. A listing of cities by states (with entry numbers in the bibliography), an author index, and a subject index complete the volume. Future editions with expanded coverage would be most welcome!-L.S.

Smith, John David. Black Slavery in the Americas: An Interdisciplinary Bibliography, 1865-1980. Westport, Conn., Greenwood Pr., 1982. 2v. (1,847p.) \$95.

LC 82-11736. ISBN 0-313-23118-4.

Black Slavery in the Americas is a major new bibliography whose focus is "slavery's institutional features in the Americas" (Introd.) and whose cited sources emphasize various aspects of slave life as seen from the slave's point of view. Coverage includes all of the Americas-North, Central, and South America and the Caribbean-and there are important chapters on slavery reference sources and on the historiography of slavery. Volume 1 is mainly concerned with slavery in the various geographic locations (e.g., Canada), while volume 2 concentrates primarily on the lives of the slaves (e.g., "Conditions of Slave Life," "Slave Religion"). The bibliography contains more than fifteen thousand citations from all disciplines but is limited to English-language materials written from 1865 to 1980 . A special effort was made to include hard-to-find materials such as conference papers, essays, and master's theses. Political writings on slavery have been excluded, as have references to fiction, poetry, and drama. In addition to the topical chapter arrangement, there is a detailed subject index and an author index. Recommended for all college and university libraries.-L.S.

\section{POLITICAL SCIENCE}

Goehlert, Robert U. and Martin, Fenton S. The Parliament of Great Britain: A Bibliography. Lexington, Mass., Lexington Books, 1983. 209p. \$24.95. LC 82-47920/ r83. ISBN 0-669-05700-2.

Researchers in British politics and history have been gifted with this very useful bibliography "on the history, development, and legislative process of Parliament" (Introd.), listing English-language books, edited volumes, original essays in compilation, journal articles, research notes and review essays, and dissertations and theses completed in the United Kingdom, the United States, and Canada. Except for dissertations and theses, only published materials are included (and any published form is preferred to the typescript dissertation or thesis). Excluded are materials on the Cabinet, the Prime Minister, and the Constitution; biographies and government documents are only selectively included.

Arrangement is topical within ten divisions ("Origins and Development of Parliament," "Pressure on Parliament," "Reform of Parliament," etc.), preceded by a section entitled "Reference Works." A very useful introduction clearly states what is included, which sources were used to compile the bibliography, and where researchers can turn for references in those areas not treated; it also discusses some of the most important sources, such as directories, dictionaries of parliamentary terms, works on the legislative process, and compilations of election statistics. The volume ends with good author and subject indexes, the latter including an arrangement for chronological periods under some of the broader terms.-E.M.

Political Parties of Europe, ed. by Vincent E. McHale. Westport, Conn., Greenwood Pr., [1983]. 2v. \$95. LC 82-15408. ISBN 0-313-21405-0.

These two volumes constitute the second installment of "The Greenwood Historical Encyclopedia of the World's Political Parties," a series which aims "to provide a comprehensive reference guide 
to all significant parties in various world regions through brief biographical sketches [of the parties], covering such bases as date and circumstances of foundation; evolution of ideology and program; evolution of organization, including splits, mergers, associations, and alliances; and impact on government and society." -Pref. The earlier portion of the series, Political Parties of the Americas (1982; 2v.) covered Canada, Latin America, and the West Indies.

This European segment is wide-ranging in its coverage, treating thirty-nine distinct party systems: tiny states such as Andorra and Liechtenstein are included; the formerly independent Baltic states of Estonia, Latvia, and Lithuania are accorded treatment separate from the Soviet Union; there are three chapters for Germany (i.e., Historical Germany, East and West Germany); and there is a chapter for the European parliament. Country sections are signed by contributing scholars, and an introductory essay and bibliography precede the alphabetical listing of each country's parties. Full information on a party (meant to be current to 1982) appears under the standard English form of the name; cross-references from vernacular and alternate party names and abbreviations are provided. Tables showing party distribution of seats over time are usually included for each country. Useful appendixes and a general index complete the work. $-E . S$.

\section{LAW}

Blandford, Linda A. and Evans, Patricia Russell. Supreme Court of the United States, 1789-1980: An Index to Opinions Arranged by Justice. Millwood, N.Y., Kraus Internat. Pubns., [1983]. 2v. $(1,126 p$.) \$85. LC 82-48981. ISBN 0-52727952-8.

"Sponsored by the Supreme Court Historical Society." - t.p.

This is the first reference source to index cases before the Supreme Court by the individual Justice, thus saving the user a tedious search through United States Reports. The index is arranged chronologically by dates of service for each Justice, from
James Wilson in 1789 to John Paul Stevens in 1975, with coverage through the October 1979 term, which ended September 18,1980 . Opinions for each Justice are arranged in seven groups: the three standard categories of Supreme Court decisions-majority, concurring, and dissenting opinions; opinions announcing judgment for plurality opinions where there is no single Court opinion; separate opinions, including those that are both concurring and dissenting in part; opinions as Circuit Justice, which include those published in sources other than United States Reports from 1926 to 1969 ; and statements made to the reporter of the decisions. Complete references to the texts in the Reports are given for all opinions.

Two appendixes provide some biographical details on individual Justices (place and date of birth, service on the Court, death date), as well as a table of succession of the Justices showing a chronology of years of active service on the Court. There is also an alphabetical list/index of Justices. No attempt was made to distinguish opinions by subject matter, except in the case of the recurring death penalty statement of Justices Brennan and Marshall. The compilers have provided unique and valuable access to Supreme Court history and its decisions for nearly two hundred years; historians, political scientists, and legal researchers will welcome their meticulous work.-D.G.

\section{HISTORY}

Cook, Chris and Stevenson, John. The Longman Handbook of Modern British History, 1714-1980. London \& N.Y., Longman, 1983. 380p. £12.95; \$25. LC 81-23621. ISBN 0-582-48581-9.

This is a curious book. On the one hand it is meant as a handbook "bringing together a wealth of chronological, statistical and tabular information which is not to be found elsewhere within the confines of a single volume." - Pref. On the other, it is a syllabus including "those facts, figures and statistics that we believe are most needed for courses in later modern British history." The chronologies, definitions, and tables are organized into four divi- 
sions: "Political History," "Social and Religious history," "Economic History," "Foreign Affairs and Defence." These sections are followed by capsule biographies, a glossary of terms, and a bibliography treating thirty-four broad topics (e.g., Pitt and Fox, the Industrial Revolution). For each of these huge areas, the compilers give a selected list of primary and secondary works, along with essay topics and a paragraph suggesting approaches to presenting the topic.

A brief description of a section may serve to show the variety of information presented. The "Social and Religious History" section is subdivided for population, education, social reform, housing, women, press and broadcasting, crime and police, labor, etc., and each subsection begins with a chronology of major events ("The development of the police," "Major popular disturbances and demonstrations") and tables of statistics ("Committals of indictable offenses 1805-1856,"' "Crimes known to the police 1857-1978," "Numbers transported to Australia. . . ," "Traffic offenses 1900-1970," etc.). Many of the tables are reprinted from other compilations such as Trends in British Society Since 1900 (1972) or Abstract of British Historical Statistics (Guide CG132) or from other books and articles, but some tables cite no source at all.

For libraries lacking the standard sources for British history, this compilation could be quite useful; for research libraries it could be handy for quick reference, but more as an "extra" than a necessary purchase. As a study guide it would seem to work very well, and there is a paperback edition, which is available at a more affordable $£ 6.95$ (\$13.95). - E.M.

King, David James Cathcart. Castellarium Anglicanum: An Index and Bibliography of the Castles in England, Wales, and the Islands. Millwood, N.Y., Kraus Internat. Pubns., 1983. 2v. (lxviii, 676p.) il. \$150. LC 81-20812. ISBN 0-527-50110-7.

The fruit of years of research is presented in this inventory of all castles of England and Wales, including possible and vanished castles as well as extant ones. King's inventory also encompasses "all serious fortification-including town walls, fortified monasteries, and defences of other secular and religious communities-built in the period between the date of the first recorded castle (which at present stands at 1051-2) and the death of Henry VIII in 1547."'-p.lix. Arrangement is by county, subdivided by category (extant castles, strong houses, rejects, walled towns, etc.) within which is a description of each building. Even though each edifice is accorded only a paragraph, quite a bit of information is presented: name, location on an ordnance map, brief description, history as culled from contemporary and other sources, present condition if appropriate, concise bibliography of secondary sources. For each county there is a general statement on the types of castles, etc., as well as a statistical count of each category of building.

Short, useful essays on the definition, character, and distribution of castles, and a survey of past efforts to record castles in England introduce the catalog. The volumes end with a glossary, a bibliography of secondary literature published through 1979, and name and place indexes. Drawings and maps are scattered throughout, and twenty-three photographic plates are grouped at the end of V.2. Historians, archaeologists, art and literary historians will bless King for his painstaking work; tourists may find the volumes of interest for planning a vacation or study trip.E.M.

Studying the Presidency. Ed. by George C. Edwards III and Stephen J. Wayne. Knoxville, Univ. of Tennessee Pr., [1983]. 312p. \$19.95. LC 82-17472. ISBN 0-87049-378-7.

Expressing the view that study of the United States presidency is only just coming into its own, the editors have here brought together a series of essays by various hands suggesting methodology and offering advice to the researcher embarking on work in this field. The volume is in two sections: (1) "Approaches and Analyses" and (2) "Data Sources and Techniques," the latter providing chapters on information sources (including online databases), the use of legal sources, mak- 
ing the most of presidential libraries, and tips on interviewing presidential aides. This is an interesting and informative guide for a fairly specialized area.-E.S.

\section{NEW EDITIONS, SUPPLEMENTS, ETC.}

Some eighteen hundred terms from the fields of book publishing, book manufacturing, bookselling, the antiquarian book trade, and librarianship are defined in the sixth edition of The Bookman's Glossary (N.Y., Bowker, 1983. 223p. \$21.95). Compiled under the editorship of Jean Peters, it is "the first book from the Bowker Book Division to use an electronic text management system in its editing and composition" (Pref.), and future editions can be produced from the database created by that system.

The Concise Oxford English-Arabic Dictionary of Current Usage, edited by N. S. Doniach (London, Oxford Univ. Pr., 1982. 461p. £6.95) is "a shortened and up-dated form of the 1972 Oxford English Arabic Dictionary [Guide AD156], ... . designed to meet the needs both of the Arabic speaker who is learning English and of the English speaker who is learning Arabic." -Pref. Similarly, Harrap's Shorter French and English Dictionary (London, Harrap, 1982. 798p. £9.95) is "a condensed version of Harrap's New Standard French and English Dictionary [rev. ed., $1980.2 v$.] with a certain number of modifications and additions to bring the text fully up to date." - Pref.

Langenscheidt's Condensed Muret-Sanders German Dictionary: German-English, edited by Heinz Messinger (Berlin, Langenscheidt, 1982. 1,296p. \$70) is based on the German-English part of the four-volume Muret-Sanders published 1962-75 (Guide AD332). This hefty volume "is by no means simply the result of a systematic halving of the larger dictionary," but involved "a word-for-word scrutiny and careful sifting of the original material." Pref. There are about fourteen thousand entry words.

With the publication of V.22 (Wi-Zy), the Personal Name Index to 'The New York Times Index,' 1851-1974, compiled by Byron A.
Falk, Jr., and Valerie R. Falk (Verdi, Nev., Roxbury Data Interface, 1976-83) is now complete. Plans have been announced for a first supplement, which will not only index the 1975-79 volumes of the New York Times Index, but will include names that were missed in the earlier volumes or that had not yet been published in the printed volumes of that index at the time the Falk compilation (see Suppl. AF10) began to appear.

"Public Documents: An Overview" is the new first chapter of the third edition of Joe Morehead's Introduction to United States Public Documents (Littleton, Colo., Libraries Unlimited, 1983. 309p. \$28.50). The work has undergone a thorough revision and updating since the 1978 edition (Suppl. AG5). The latest volume in The $\mathrm{Cu}$ mulated Indexes to the Public Papers of the Presidents of the United States series is that covering the term of Jimmy Carter, 1977-1981 (Millwood, N.Y., Kraus International Pubns., 1983. 391p. \$65). It cumulates the indexes from the individual volumes of the Carter papers as published in the government-sponsored collection (see Guide AG40), adding see and see also references as needed.

More than sixteen hundred organizations are listed and described in the second edition of The Directory of Religious Organizations in the United States (Falls Church, Va., McGrath, 1982. 518p. \$75). Unlike the 1977 edition, this volume excludes religious orders and is concerned only with general organizationsdepartments of national churches, professional associations, volunteer groups, government agencies, businesses, and fraternal societies that have a religious purpose. Organizations are listed alphabetically; information includes religious affiliation, principal officer, address, statement of purpose and activities, founding date, membership, publications, etc. An index to types of activity would have been helpful.

Arabic Linguistics: An Introduction and Bibliography by M. H. Bakalla (London, Mansell, 1983. 741p. \$44) is a revised and greatly enlarged edition of the compiler's Bibliography of Arabic Linguistics (1975; Suppl. BC25). It lists about fifty-five hun- 
dred items in some twenty languages, with separate sections for Occidental and Oriental materials. There is a subject index and indexes of authors, editors, translators, and reviewers.

The Continental Novel: A Checklist of Criticism in English, 1967-1980 by Louise S. Fitzgerald and Elizabeth I. Kearney (Metuchen, N.J., Scarecrow Pr., 1983. 496p. $\$ 29.50$ ) continues the listings in the compilers' earlier volume of similar title (Guide BD201) which covered 1900-66. There are again sections for the French, Spanish and Portuguese, Italian, German, Scandinavian, and the Russian and East European novel.

More than thirty-three hundred items of scholarship from the 1959-79 period are cited and annotated in "The Seventeenth Century Supplement" (Syracuse, Syracuse Univ. Pr., 1983. 460p. \$65), which forms volume IIIA of $A$ Critical Bibliography of French Literature (Guide BD708). Edited by $\mathrm{H}$. Gaston Hall, the volume supplements the Edelman/Brody volume of $C B F L$, and entries are numbered sequentially with that work. Owing to various delays and subsequent editorial decisions, "the user may be less assured that exclusions for 1977-78 are deliberate than for earlier years, while partial coverage of 1979 is offered for future convenience and not for completeness."-Introd. Despite that disclaimer, the new addition to the "Cabeen" series is most welcome.

The London Stage, 1910-1919: A Calendar of Plays and Players by J. P. Wearing (Metuchen, N.J., Scarecrow Pr., 1982. 2v. \$65) is the third series of similar calendars by the compiler, the earlier volumes having covered 1890-99 (see Suppl. BG12) and 1900-09 (publ. 1981). This work provides a chronological listing of 3,278 productions at thirty-nine London theaters, giving information such as genre of the play, authorship, length of run, details of cast, production staff, and references to firstnight reviews. There is an index of titles and a general index of names of authors, actors, proprietors, etc.

About thirteen thousand screen personalities (mainly American, British, French, and German) who died during the 1905-82 period are accorded entries in the third edition of Evelyn Mack Truittt's Who Was Who on Screen (N.Y., Bowker, 1983. 788 p. \$65). A typical entry includes dates and places of birth and death, a brief identifying statement, and a list of films (with dates) in which the person appeared. The "on screen" of the title is in earnest: directors, scriptwriters, etc., are included only if they actually appeared in a film or films.

It may be disappointing to find that most of the figures (on enrollment, finances, etc.) in the long-awaited twelfth edition of the American Council on Education's American Universities and Colleges (N.Y., W. de Gruyter, 1983. 2,156p. $\$ 99.50$ ) date from 1980 , yet this is understandable in view of the magnitude of the task of compilation. The volume brings together a wealth of information on 1,728 individual institutions, along with surveys of undergraduate, graduate, and professional education (incorporating numerous useful lists and tables), and extensive appendixes relating to earned doctorates.

Revision of some earlier tables as well as updating of continuing series makes the second edition of Historical Statistics of Canada (Ottawa, Statistics Canada in joint sponsorship with the Social Science Federation of Canada, 1983. unpaged. \$60; $\$ 72$ outside Canada) all the more welcome. Edited by the late F. H. Leacy, the volume follows the pattern of the 1965 edition (Guide CG101) but has "more distinctly identified sections on Vital Statistics and Health; Social Security; Minerals; and Energy."'-Pref. Unfortunately there were publication delays, and most series end in 1975, with only a few carrying the record through 1976 or 1977.

Index to Periodical Articles on South African Political and Social History Since 1902, compiled by P. W. Coetzer and J. H. Le Roux (Boston, G. K. Hall, 1982. 616p. \$69.95) forms V. 3 of Bibliographies on South African Political History (Suppl. 2CJ101). Arrangement is by broad topics, with author and subject indexes. Emphasis is on South African periodicals, but relevant articles from a wide range of European and American journals are listed.

Mexican Political Biographies, 1935-1981 by Roderic Ai Camp (Tucson, Univ. of Arizona Pr., 1982. 447p. \$35) is a revised and 
expanded edition of the compiler's 1976 volume of similar title (Suppl. CJ127). Completely reset and using a doublecolumn page of slightly larger size, the new work not only adds some 450 new biographies, but introduces significant changes and updatings in many of the 900 original sketches.

Robert H. Becker's revised and enlarged fourth edition of The Plains and the Rockies: A Critical Bibliography of Exploration, Adventure and Travel in the American West, $1800-1865$ by Henry R. Wagner and Charles L. Camp (San Francisco, John Howell-Books, 1982.745p. \$150) describes some eighteen hundred issues and editions of nearly 690 individual works. Structure (i.e., by year, then by author) and numbering of the earlier editions (Guide DB82) have been retained.

The new edition of the Concise Dictionary of American History (N.Y., Scribner, 1983. $1,140$ p. $\$ 60)$ is an abridgment of the eightvolume Dictionary of American History (1976; Suppl. DB36). It offers condensed versions of more than six thousand articles found in the parent set, retaining the essential information and adapting it to ready-reference use.-E.S. 